\section{Spinal Intradural Schwannoma with Torsion: A Case Report}

\author{
염전을 동반한 척추 경막 내 신경집종: 증례 보고
}

So Jeong Lee, $\mathrm{MD}^{1}{ }^{(\mathbb{D})}$, Sang Yoon Kim, MD ${ }^{1 *}$ (D)

Young Jin Kim, MD² ${ }^{\mathbb{D}}$, Kyeong-Wook Yoon, MD²

Departments of ${ }^{1}$ Radiology, ${ }^{2}$ Neurosurgery, Dankook University Hospital, Cheonan, Korea

Intradural schwannoma accompanied with torsion is rare. Intradural lumbar schwannoma was found in a 63-year-old man presenting with right sacral pain radiating to the lower extremity. This mass showed minimal enhancement on MRI. The tumor's location changed each time on MRI and CT-myelography. The patient underwent surgical resection and the cauda equina, linked to this schwannoma, was severely twisted.

Index terms Schwannoma; Torsion, Mechanical; Spine; Cauda Equina

\section{서론}

신경집종(schwannoma)은 전신에서 발생하는 양성 말초신경초 종양으로 척추 경막 내 종양의 25 30\%를 차지한다(1). 척추 경막 내 신경집종에서 염전이 동반되는 경우는 매우 드 물며 국내에서는 보고된 바가 없다(2). 저자들은 점점 악화되는 방사통을 주소로 내원한 63 세 남자의 말총에서 기원하며 염전을 동반한 신경집종 1 예를 경험하였기에 문헌고찰과 함 께 이를 보고하고자 한다.

\section{증례 보고}

63세 남자 환자가 우측 엉치 통증 및 하지 방사통을 주소로 내원하였다. 환자는 내원 6개 월 전부터 증상이 있었으며 최근에 급격히 심해졌다고 하였다. 외부 병원에서 이에 대해 신 경차단술을 시행 받았으나 효과가 없어 본원 신경외과 외래에 내원하였다. 내원 당시 신경 학적 검사상 근력 저하는 없었으나 감각피부분절이 명확하게 나누어지지 않는 저림 감을 포 함한 감각이상 및 통증이 있었다.

내원 10 주 전에 외부 병원에서 시행한 자기공명영상(이하 MRI)에서 경계가 불명확한 결 절성 병변이 제 2 번 요추 수준의 경막 내에 위치해 있었다. 이 병변은 $\mathrm{T} 2$ 강조 시상 영상에서
Received December 27, 2019

Revised March 7, 2020

Accepted April 2, 2020

${ }^{\star}$ Corresponding author

Sang Yoon Kim, MD

Department of Radiology,

Dankook University Hospital,

201 Manghyang-ro, Dongnam-gu, Cheonan 31116, Korea.

Tel 82-41-550-6921

Fax 82-41-552-9674

E-mail minipacs@dkuh.co.kr

This is an Open Access article distributed under the terms of the Creative Commons Attribution Non-Commercial License (https://creativecommons.org/ licenses/by-nc/4.0) which permits unrestricted non-commercial use, distribution, and reproduction in any medium, provided the original work is properly cited.

\section{ORCID iDs}

So Jeong Lee (1D) https:// orcid.org/0000-0002-5673-7365 Sang Yoon Kim (iD https:// orcid.org/0000-0001-9951-2505 Young Jin Kim (D) https:// orcid.org/0000-0002-1508-4919 Kyeong-Wook Yoon (D) https:// orcid.org/0000-0002-2949-8506 
는 척수와 동등하거나 약간 높은 신호 강도를, $\mathrm{T} 1$ 강조 시상 영상에서는 척수와 유사한 신호 강도 를 보였다(Fig. $1 \mathrm{~A}$ ). 외부 병원에서 MRI를 시행한지 11주 후에 본원에서 시행한 조영증강 MRI 상, $\mathrm{T} 2$ 강조 시상 영상에서 결절성 병변의 위치가 이전과 비교하여 약간 꼬리 쪽으로 이동한 것을 확 인하였다. 조영 후 $\mathrm{T} 1$ 강조 영상에서는 병변의 대부분이 조영되지 않고 일부분만 약한 조영증강을 보였다(Fig. 1B). 이틀 후 시행한 척수조영-전산화단층촬영(CT-myelography) 영상에서는 병변이 다시 머리 쪽으로 약간 이동하였다. 또한 병변의 꼬리 쪽으로 병변과 연결되어 줄기처럼 보이는 부분이 관찰되었다(Fig. 1C).

환자는 병변에 대해 수술을 시행 받았는데, 수술 시에 경막 내의 병변은 말총과 연결되어 있었 으며 병변의 머리와 꼬리 쪽으로 연결된 말총이 서로 꼬여서 염전 되어 있었다(Fig. 1D). 제2번 요추의 척추추궁절제술과 함께, 병변과 연결된 말총을 절제하여 병변을 제거하였다. 이 병변은 $1.3 \mathrm{~cm} \times 0.9 \mathrm{~cm}$ 크기의 육안적으로 검붉은 색을 띠는 종괴였고, 조직병리학적으로는 신경계 기 원 세포를 가지고 세포면역화학염색 상 S-100 protein에 양성을 보여 신경집종으로 최종 진단되 었다. 종괴의 대부분이 괴사 되어 있었으며 종괴 내부에 울혈된 정맥이나 출혈의 소견은 없었다 (Fig. 1E). 수술 후 환자의 증상은 호전되었다.

\section{고찰}

척추 경막 내 신경집종의 증상은 병변의 위치에 따라 무증상에서, 요통, 방사통 그리고 천천히 진행하는 신경학적 결함까지 다양하게 나타날 수 있다 $(1,3)$. 이전에 보고된 증례들 $(2,4,5)$ 에 따르 면 염전이 동반된 신경집종의 증상은 갑자기 발생하는 감각저하, 허리통증, 통증으로 인한 보행장 애, 급성 요폐 등이 있고, 심한 경우에서는 정신 혼동까지도 동반될 수 있다고 하였다.

척추 경막 내 신경집종의 염전의 발생 기전은 아직 명확하게 밝혀지지 않았다. 말총이 있는 수 준의 경막 내 공간은 작은 신경집종이 움직이거나 회전하기에 충분하다고 한다. Jenkins 등(4)은 경막 내에서 한쪽 방향으로 회전한 종괴가 종양 표면의 비균질성이나 표면과 거미막의 유착으로 인해 한쪽 방향으로 종괴가 회전하고 다시 반대로 회전하지 못한다는 래칫 메커니즘(ratcheting mechanism)을 염전의 발생기전으로 제시한 바 있다.

전형적인 신경집종은 $\mathrm{MRT} 1$ 강조 영상에서는 척수와 비슷한 신호 강도를 보이고 $\mathrm{T} 2$ 강조 영상 에서는 그보다 높은 신호 강도를 보인다. 조영증강 영상에서는 일반적으로 강하고 균질한 조영증 강을 보이지만 종괴 내부의 혈관성의 정도, 낭성 변화, 허혈성 변화 및 출혈 등의 동반 여부에 따라 다양하게 보일 수 있다(3). 염전이 동반된 신경집종의 증례 보고 $(2,4,5)$ 들에 의하면 조영이 잘되지 않는 경우가 많은데, 이는 신경집종으로의 지속적인 혈류 감소로 인한 것으로 추측되며(6), 본 증 례에서는 염전으로 인한 혈류 감소와 더불어 종괴 내부의 괴사도 낮은 조영증강의 원인이 되었던 것으로 생각된다(2, 4-6).

$\mathrm{MRI}$ 소견을 바탕으로 감별해야 하는 질환으로 경막 내 추간판 탈출(intradural disc herniation)이 있겠다. 일반적으로 탈출된 추간판은 원래의 추간판 후방 변연부와 서로 연결성을 보이지 만, 경막 내로 분리(sequestration) 된 추간판은 경막 내 종양과 감별이 어려울 수 있다. Aydin 등 
(7)은 경막 내 추간판 탈출을 척추 종양으로 오인한 증례를 보고하였다. 이 증례의 MRI에서 경막 내로 탈출된 추간판은 $\mathrm{T} 1$ 강조 영상에서 낮은 신호 강도, $\mathrm{T} 2$ 강조 영상에서 약간 높은 신호 강도를 보였고, 조영증강 $\mathrm{T} 1$ 강조 영상에서 종괴의 변연부가 조영증강되는 소견을 보여 경막 내 종양처럼 보였다. 본 증례에서도 병변의 낮은 조영 정도, 병변과 인접한 제2 3번 요추 사이의 추간판 탈출과 그 주변 부위의 조영증강, 추적 영상 검사에서 병변의 위치 변화 그리고 환자의 급격한 증상 악화

Fig. 1. Intradural lumbar schwannoma with torsion in a 63-year-old man.

A. Axial and sagittal T2-weighted images (left upper and lower) show an ill-defined iso to high signal intensity lesion (arrows) in the intradural space at the lower $\mathrm{L} 2$ level. This lesion is seen as iso signal intensity on T1-weighted images (right upper and lower).

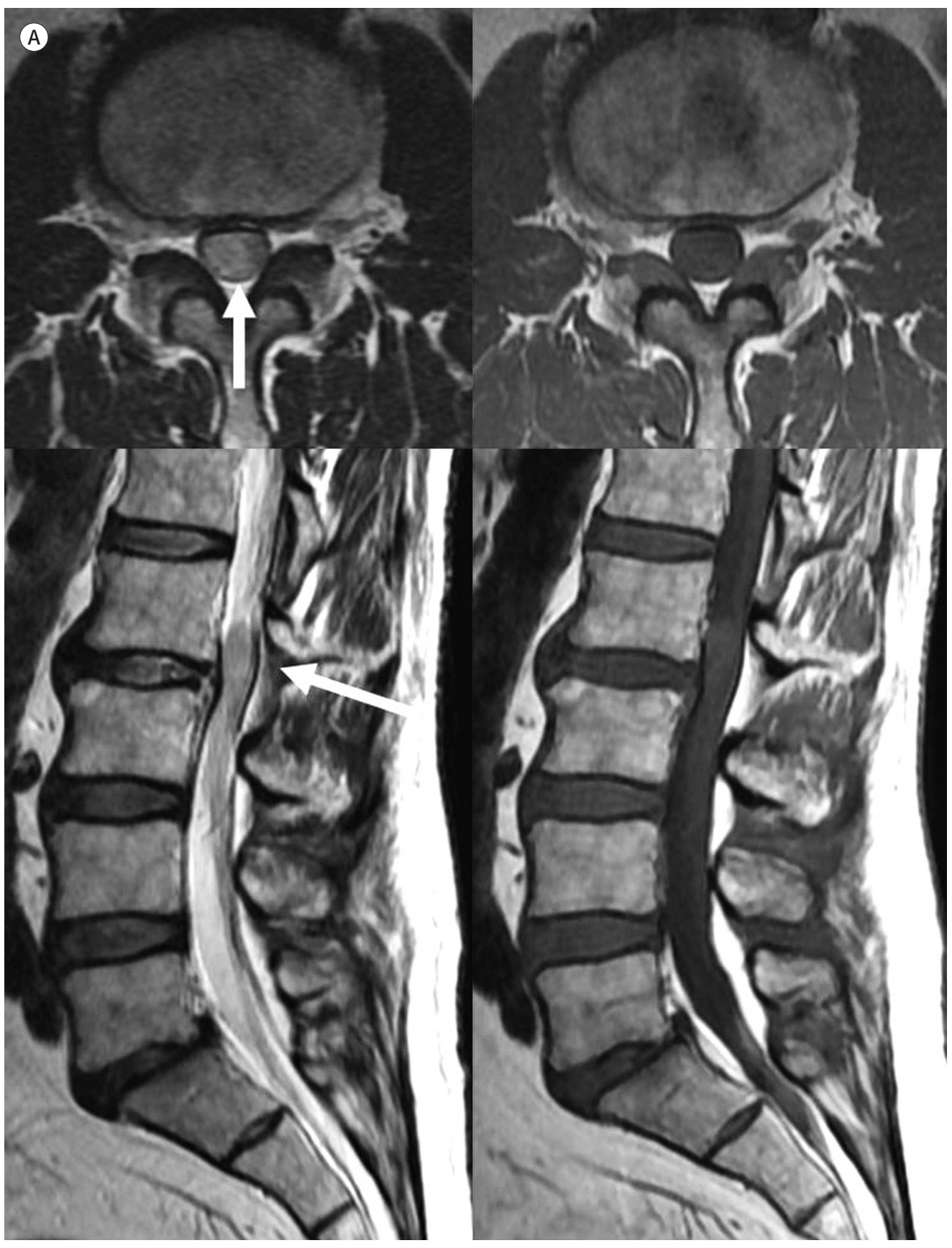


Fig. 1. Intradural lumbar schwannoma with torsion in a 63-year-old man.

B. A follow-up sagittal T2-weighted image (left) shows a well-circumscribed mass (white arrow) in the intradural space at the L2-3 disc level. A contrast-enhanced T1-weighted image (right) shows faint enhancement in the upper portion of the mass (black arrow) but weak enhancement in most of the mass.

C. Axial (left) and sagittal (right) CT-myelography demonstrate the mass (asterisk) located in the intradural space at the L2-3 disc level. A stalklike structure (arrow) is seen at the caudal aspect of the mass (asterisk) on the sagittal image.

D. Intraoperative photographs show that the tumor (left, asterisk) is located in the intradural space at the L2-3 level. Rotation of the proximal cauda equina (middle, arrow) is observed. A gross specimen (right) demonstrates a dark-reddish mass measuring $1.3 \mathrm{~cm}$.
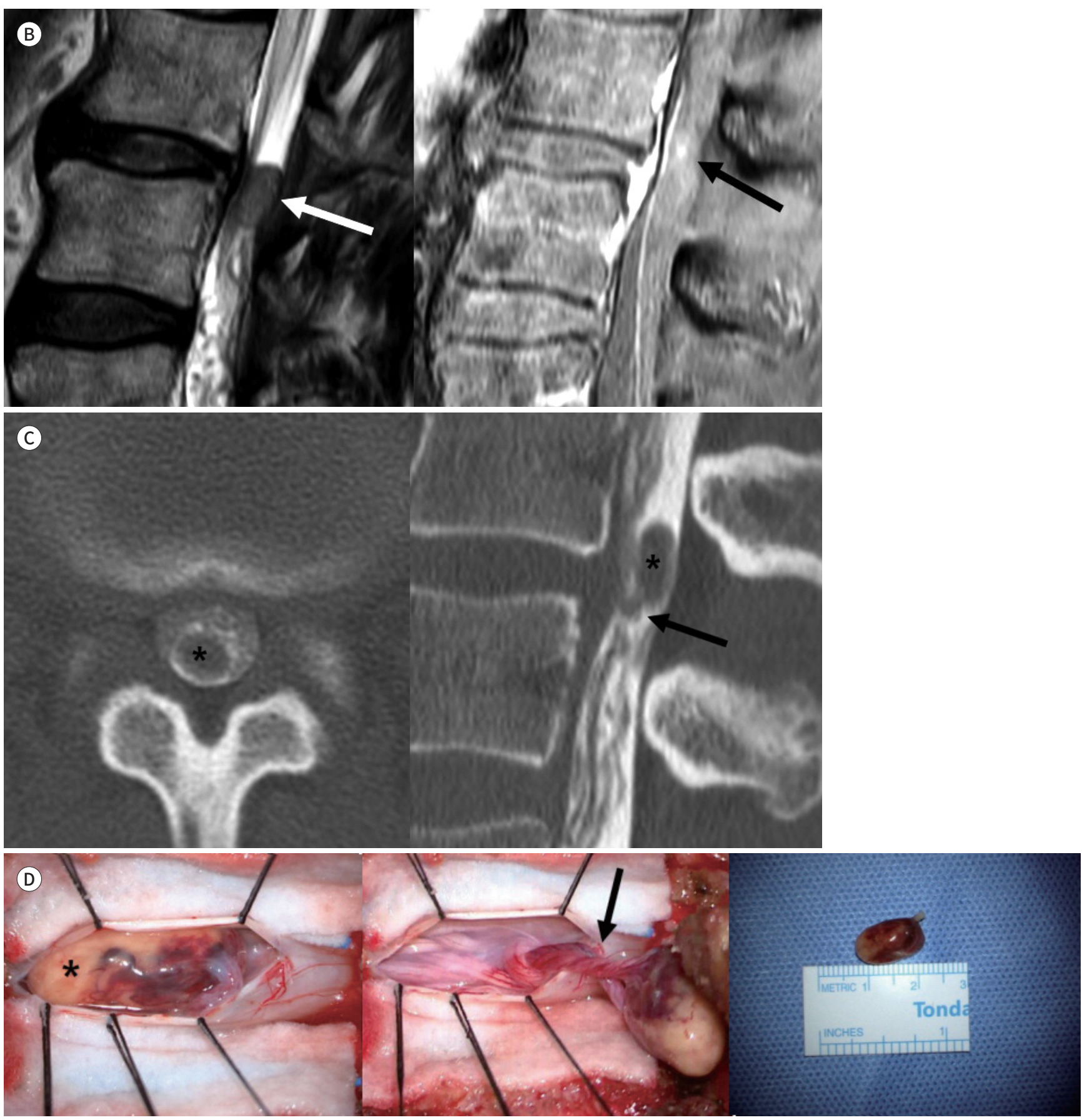
Fig. 1. Intradural lumbar schwannoma with torsion in a 63-year-old man.

E. A photomicrograph of the mass (left, H\&E stain, $\times 10$ ) reveals the narrow stalk (arrow) in the caudal area. Microscopic findings demonstrate diffuse infiltration of the spindle cells only in the peripheral portion of the mass and necrosis of most of the mass (middle, H\&E stain, $\times 100$ ). Immunohistochemical staining (right, $\times 100$ ) reveals diffuse positivity for S-100 protein of tumor cells, indicating neural crest cells.

$\mathrm{H} \& \mathrm{E}=$ hematoxylin and eosin
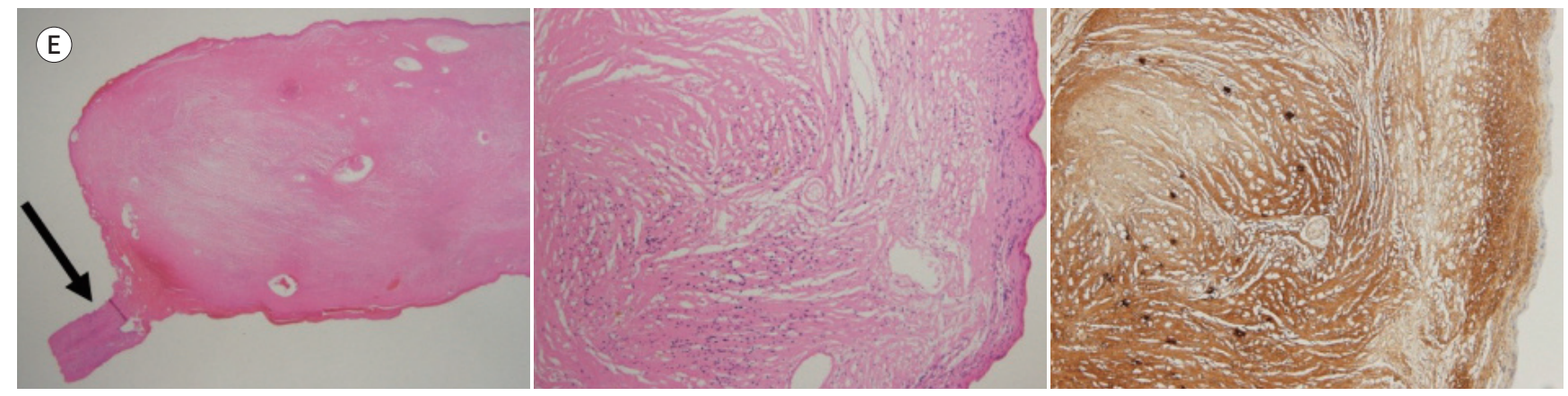

등은 경막 내 추간판 탈출의 가능성을 배제할 수 없는 소견들이었다.

만약 $\mathrm{MRI}$ 에서 염전이 동반된 신경집종이 의심되면 다음 검사 또는 추적 관찰 시 척수조영-전산 화단층촬영(CT-myelography) 영상을 시행해 보는 것이 도움이 될 수 있겠다. 본 증례에서는 척수 조영술을 통해 MRI보다 더 높은 대조도로 종양의 경계와, 줄기같이 꼬여있는 말총을 좀 더 상세 하게 관찰할 수 있었다. 만약 경막 내 추간판 탈출로 인해 경막의 손상이 있다면, 손상 부위를 통한 척수액의 누출을 확인하기에도 척수조영술이 용이하기 때문에 경막 내 추간판 탈출을 감별하는 데 도움이 될 수 있겠다.

요약하면, 염전을 동반한 경막 내 신경집종은 조영증강 $\mathrm{MRI}$ 에서 낮은 조영증강을 보이며, 검사 할 때마다 종괴의 위치가 조금씩 다르게 보일 수 있다. 염전이 동반된 신경집종이 의심되면 다음 검사 또는 추적 관찰 시 척수조영-전산화단층촬영(CT-myelography)을 시행해 보는 것이 감별 진 단에 도움이 될 수 있겠다.

\section{Author Contributions}

Conceptualization, K.S.Y., K.Y.J., Y.K.; investigation, L.S.J., Y.K.; supervision, K.S.Y., K.Y.J.; writingoriginal draft, L.S.J., K.S.Y.; and writing-review \& editing, K.S.Y., K.Y.J., Y.K.

\section{Conflicts of Interest}

The authors have no potential conflicts of interest to disclose.

\section{REFERENCES}

1. Crist J, Hodge JR, Frick M, Leung FP, Hsu E, Gi MT, et al. Magnetic resonance imaging appearance of schwannomas from head to toe: a pictorial review. J Clin Imaging Sci 2017;7:38

2. Khoshyomn S, Barth KN, Christman RA, Braff SP, Wilson JT. Torsion of a lumbar nerve root schwannoma. Pediatr Neurosurg 2002;37:206-209

3. Abul-Kasim K, Thurnher MM, McKeever P, Sundgren PC. Intradural spinal tumors: current classification and MRI features. Neuroradiology 2008;50:301-314

4. Jenkins AL 3rd, Ahuja A, Oliff AH, Sobotka S. Spinal schwannoma presenting due to torsion and hemorrhage: case report and review of literature. Spine J 2015;15:e1-e4

5. Choy W, Khanna R, Ortmeier TC, Tapia-Zegarra GG, Lindley TE, Smith ZA et al. Acute presentation of lumbar 
spinal schwannoma due to torsion: a case report. Cureus 2016;8:e586

6. Shrier DA, Rubio A, Numaguchi Y, Powers JM. Infarcted spinal schwannoma: an unusual MR finding. AJNR Am J Neuroradiol 1996;17:1566-1568

7. Aydin MV, Ozel S, Sen O, Erdogan B, Yildirim T. Intradural disc mimicking: a spinal tumor lesion. Spinal Cord 2004; $42: 52-54$

염전을 동반한 척추 경막 내 신경집종: 증례 보고

이소정 1 김상윤 ${ }^{*} \cdot$ 김영진 ${ }^{2} \cdot$ 윤경욱 $^{2}$

척추 경막 내 신경집종에 염전이 동반되는 경우는 드물다. 우측 엉치 통증과 하지 방사통을 주소로 내원한 63세 남자의 요추 수준에서 경막 내 신경집종이 발견되었다. 이 신경집종은 조영증강 자기공명영상에서 조영증강이 잘되지 않았고, 자기공명영상 및 척수조영-전산화단 층촬영 영상에서 검사할 때마다 위치가 바뀌었다. 환자는 수술적 절제를 받았으며 신경집종 은 염전을 동반하고 있었다.

단국대학교병원 ${ }^{1}$ 영상의학과, ${ }^{2}$ 신경외과 